\title{
The Analytical of Sports Behavior and Current College Girl Sports Values
}

\author{
Tianxue Jin \\ Shangdong Woman University \\ Jinan, China \\ Jintian129@163.com
}

\begin{abstract}
In view of the current university students towards the physical activity has positive and negative attitude toward behavior, heart is like the body very repugnant phenomenon, reasons for such phenomenon from the aspects of analysis, and through the full understanding of the value of $P E$, correlation analysis between the two, in order to understand the fundamental physical activities the contradiction between the university girls treated, and provide a theoretical basis and support for the development of college women's sports.
\end{abstract}

Keywords-component; Sports; College Girl; values sports behavior

\section{OBJECTIVE}

the literature and investigation the author understands the female treats sports there is such a phenomenon, most of the female students view on sports are very active, they clearly understand sports in physical health, improve personal qualities, reduce psychological pressure, improve the quality of will has a very active role, and also to the number of sports some itch for a try ideas, but can be thought to act but only a minority, most girls will idea to act before it stopped. As everyone knows value refers to the total evaluation of objective things a person around the significance, importance and total view of the. It represents the views and behavior tendency of a person to the things around, also is the personal things on a good and evil, is the evaluation of non and importance of [1]. As well as the value orientation, the pursuit of value, the value of setting goals for certain; on the other hand the measure of value and performance criteria, become people to judge the value of things without value evaluation and value standard. Personal values once established, it has relative stability. Think of all the things in the order of priorities, in the eyes of the weight, constitute a system of values. On the value and the value system is the psychological base determines the behavior of people. But the sports values are people and social needs of view to sports as a social phenomenon, which determines what the sports behavior choice is [2]; the people according to the long-term physical exercise and repetitive physical and emotional experience, between value attribute, the main object of sports sports value relations, as well as some form of sport between value creation activities, set the relative stability of the psychological and behavior or psychological and behavior gradually formed. It is peculiar to people the importance of understanding and evaluation of physical education and sports phenomenon for themselves and the society of the internal standard. The individual is always in accordance with their own values to determine their physical education objective, and to actively engage in sports activities. It is people's motivation, under certain circumstances, the objective needs and emotions will reflect the comprehensive. Colleagues sports value and new ideas including the sports socialization, multidimensional sports view, school sports space extension concept, the multidimensional view of sports content is as follows: the concept of sports service goods; sports competition; sports industry development, can promote social and economic prosperity; sports social function concept of multidimensional view of sports [3]. So the influence of sports values is very extensive, affecting social development at the same time, on a personal physical behavior influence, and even play a decisive role.

\section{EFFECT OF THE CHARACTERISTICS OF SPORTS VALUES IN SPORTS BEHAVIOR}

\section{A. The subjective view of sports value and sports behavior}

Sports value concept belongs to the field of ideology, with its main body color is very strong. There are significant differences between different individual cognitive level, these will make them have different sports demand. Physical demand is the foundation and starting point for the formation of sports values, behavior subject will be for sports demand different and the formation of different sports values, so the actors because of their different needs and show different sports behavior. Because of the ideology and cognitive level is influenced by external factors, such as the standards of living, the influence of family environment, parents and teachers guide and so on, all of these will have a greater impact on contemporary female college students as the main form in the process of development of sports ideology and on sports cognition level.

\section{B. The selectivity view of sports value and sports behavior}

Sports value is selected to obtain, is deep, rich. This selective must be free not to force the. Because the sports values is based on the human brain based generation, each individual has many different sports value in the growth stage of each of the different views are available, also show different effects of different choice of sports behavior. The contemporary female college students in the rapid development period of China economy, overall environment 
highlights the fast rhythm, so most of the female students are also affected by the hope oneself can also want to the rapid development of the economy can efficiently and save energy, due to participate in any kind of sports don't get something for nothing, so the choice of efficient sports values in female college students long and hard before the physical behavior of fear and regress. Only those who choose to work steadily, not radical, students will be pain and joy brought not impetuous to experience the movement overcome various unfavorable factors to insist on his own movement.

\section{The Stability view of sports value and sports behavior}

Values of physical education is a kind of relatively long-lasting sports faith individual has, the more stable belief can make the physical behavior of individual consistently towards a physical target, and to realize the target of physical effort. Affect the stability of sports values in sports behavior also has two sides, on one hand, positive, active if the contemporary female college students as subjects of sports values, so they can long exercise project of their choice, even will not give up his love in a bad condition. But if they sports values is impulsive, aggressive, so often showed that even their exercise programs are good at, or even has a very excellent sports facilities, they will after several sports experience will no longer continue to adhere to, but in a very long period of time will not again choose to exercise.

\section{The selectivity view of sports value and sports behavior}

Sports value is objective, is independent of the will of the people, is the product of socialization of subject. The physical needs of the people is a reflection of objective fitness, entertainment and other attributes of sports has in the consciousness of people, is an objective need to actually being aware of the existence of the. With the development of social productive forces, people's understanding of sports function, attribute is increasing gradually, new sports function has been found, recognized and accepted, people will have a new demand for sports, so in different societies and different historical periods will form different sports values. Because of the social and historical reasons, in the past, women and even the whole society is the participation of women in sports negative attitude, so for the female form sports values is not to participate in sports, sports are not suitable for women, exercise on female body good health and so on, with the development of society and the progress of human rights, women are gradually a full range into sports, but the formation of the women in the developed world situation of sports values is more stable, higher physical activity participation ratio, although our country economy rapid development in two thousand years, but bound by traditional thinking, a lot of people thought did not truly equality between men and women, including women itself, so the social historic view of sports value still has a certain influence on the physical behavior of female college students.

\section{E. The Stage view of sports value and sports behavior}

Sports values are not the same,understanding and view their view of sports value in the stage of life is different for each person are not the same, so the view of sports value forming process of actual people is constantly break the old sports value concept model, process gradually formed and established a new view of sports value. Therefore, in the view of sports value process has the development change and stage, also have different effects on the physical behavior of the corresponding. Because of the physiological characteristics of the female puberty, female body and hormone level will change a lot, all gone these changes that make women in childhood than boys with the movement aspect superiority, also due to physiological cycle movement has brought much inconvenience, and the demand of contemporary society for women is often focused on the tender beautiful, elegant, white, and so on, but also have a lot of female college students mistakenly think too much participation in sports will get a tan, can let oneself body muscles become more, make oneself become too powerful for sports fear away. Therefore, in today's University Campus in most women knowing that sports can give its many health benefits, but out of the external image of consideration and puberty since for physical health sports will be on their own to mislead the negative image, participating in sports staff ratio is not high.

\section{F. The Orientation view of sports value and sports behavior}

Sports values is the sports learning motivation in the most long-term goals and long-term effects of components, it can make people engaged in sports activities with greater consciousness and orientation, is the people of the sports behavior of the basic internal pointer, is to guide the various activities of the standard, plays a guiding role on the sports behavior decision.

\section{CONCLUSION}

Each person's view of sports value impact on the sports behavior has a decisive role, establish the correct values of sports for sports behavior has a positive influence. However, the formation of the view of sports value is influenced by many factors, such as different stages of university students in the social environment, family environment, school education, the traditional mode of thinking, economic and social, as well as their own awareness of sport and so on, the impact of these factors in the sports values at the same time, further affect the physical behavior of female college students. Sports values once formed, will affect the behavior of sports behavior of individual in the growth stage of a long, female college students is an important phase in his life, various cognitive gradually tend to be stable, so that the values of sport will have a guiding effect on the physical behavior of female college students later. The view of sports value is subjective and selective characteristics, female students in university period once in determining the choice of sports value is negative rather than positive, so very few sports behavior in all aspects of life will appear, which will on women's health to bury next hidden trouble of seeds.

\section{SugGeSTiONS}

Our country is in a stage of rapid economic development, leading to the pursuit of fast rhythm and the pursuit of efficient social style, people for the various interests tend to be the most efficient while ignoring the sustainable development, especially in the school life is parents expectations of students need to face all kinds of knowledge and skills training, usually sports activities are considered to 
be one of the main factors affecting their academic achievements, so Study hard in each think students heart of sports activities have some conflict, this also for university girl sports values is not positive buried the foreshadowing. Therefore, we first need to parents to establish correct physical value and correct education ideas

School education is the pursuit of high impact, in the student's reading time directly or indirectly put forward very high requirements, some schools are under the proportion the pressure, is the senior high school entrance examination and college entrance examination class sports class is cancelled, this undoubtedly enhance the students for sports misunderstanding, caused the student to form the negative values of sport, therefore, school education should be people-oriented educational policy, cultivate all-round development of students

The legacy of two thousand years of feudal history has not completely eliminated in the hearts of people think that women are inferior to men, the phenomenon still exists, for women should be done as an understanding wife and loving mother, should be gentle and virtuous, women no is the virtue of the thought still exists, because most sports have a certain exercise intensity and amount of exercise, the exercise and the majority of women a requirement of seemingly want to violate, but also lead to women's sports values is one of the main reasons for negative. Therefore, we should vigorously promote both men and women should enjoy the equal rights and obligations through various media, so that women can gain greater emancipation to a certain extent, various sports activities have more opportunities to participate in

Many women in the social, family, school and social environment influence, also began to position themselves should become the type as an understanding wife and loving mother or should be gentle and virtuous, this is their sports values to form the most important influence, also as they do not participate in various sports activities of the best. So women especially contemporary female college students should correctly realize this point, unremitting self-improvement, getting rid of all the constraints, and establish a positive view of sports value, enjoy all kinds of sports to bring health and fun.

\section{REFERENCE}

[1] Min Gong. Organizational behavior: an introduction [M]. Wuhan: Wuhan University press, 1997. pp 60

[2] Zhaohua Tang. Sports values is the lever of [J]. sports behavior. Journal of Chengdu Sport University, 1994,20 (4): pp 67 71

[3] JinpengHuang. Discussion on modern people's view of sports value [J]. Journal of Nanjing Sport Institute, 2002,16 (4): pp 18 19 